\title{
A helyi adórendszermodellek és az alkalmazott föbb helyi adónemek sajátosságai Európában
}

\section{The local tax system models and the main features of local taxes applied in Europe}

Gróf Katalin A tanulmány célja, hogy feltárja az európai országok Büki Közös Önkormányzati helyi adórendszereinek hasonlóságait és különbsé-

Hivatal geit. A helyi adórendszerek négy fö önkormányzati

E-mail: modell jellegzetességeit hordozzák magukban Eurógrofkata0109@gmail.com pában: az angolszász modell és a kontinentális modell, azon belül a germán, a francia és a skandináv modell sajátosságait. E négyféle önkormányzati rendszer helyi adóztatásának vizsgálatához négy országot választottunk ki. Annak összevetésével, hogyan működik a helyi adórendszer Angliában, Németországban, Spanyolországban és Svédországban, megállapíthatók az önkormányzati rendszerek közötti strukturális különbségek. Fontos vizsgálati szempont a helyi adóbevételeknek az önkormány-

Kulcsszavak: zati bevételeken belül betöltött szerepe, valamint az helyi adó, önkormányzatok által bevezethető adónemek típuhelyi önkormányzat, adóbevételek, sai, különös tekintettel a helyi adónemek előnyeire és az alkalmazásukból fakadó problémákra.

önkormányzati bevételi

struktúra 
The main focus of the paper is on the similarities and differences between European local tax systems, which bear the characteristics of four main governmental models: the Anglo-Saxon model, and three of the Continental models: the German, French and Scandinavian ones. In order to analyse these systems four countries have been chosen from the representatives of local public

Keywords: administration models. With the comparison of local taxes, how the local taxation works in England, local government, Germany, Spain and Sweden, the structures of lotax revenues, cal government in these countries and the role of local government tax revenues can be described highlighting the revenue structure advantages of local taxes and the problems as well.

Bekëlldve: 2016. március 3.

Elfogadva: 2016. március 31.

\section{Bevezetés}

Az egyes országok kormányai a közfeladatok egy részét alacsonyabb kormányzati szintekre delegálják, melyek ellátásának biztosítására az adóbevételek jelentik az egyik legfontosabb pénzügyi forrást. A helyi önkormányzatok a múködési kiadásaik fedezésére az állam adóbevételeiből részesednek, valamint helyi adókat vethetnek ki.

A helyi adóztatás rendkívül sokszínú képet mutat a világ országaiban, hiszen az önkormányzati rendszerek kialakulására és múködésére nem csupán az országok gazdasága, politikai berendezkedése van hatással, hanem azok történelmi és kulturális fejlődése is. Az Európában kialakult helyi adóztatási rendszerek négy fő önkormányzati közigazgatási modell jellemzőit hordozzák magukban. Jelen tanulmány ezeknek a modelleknek a sajátosságait tárja fel. Az európai tendenciák megismeréséhez mind a négy modell képviselőiból kiválasztottunk egy-egy országot. Anglia, Németország, Spanyolország és Svédország helyi adórendszerének részletes vizsgálatával így átfogó képet kapunk az Európában alkalmazott helyi adók sajátosságairól.

A vizsgált országokban múködő közigazgatási rendszerek szerkezetének összevetésével, az adóbevételek helyi költségvetésekben betöltött szerepének megállapításával és az alkalmazott adónemek részletes vizsgálatával ismerhetők meg a helyi adóztatás európai sajátosságai, melynek következtében feltárhatók az egyes helyi adórendszerek jellegzetességei és a bennük felmerülő problémák.

Területi Statisztika, 2016, 56(3): 320-345; DOI: 10.15196/TS560304 


\section{A helyi adózás jogi szabályozása Európában}

Az adóztatási gyakorlat elemzéséhez elengedhetetlen a helyi adózásra vonatkozó európai egységes jog tanulmányozása. Kontinensünk legtöbb országának elsődleges jogforrásai a helyi adóztatásra vonatkozóan az Európai Unió irányelvei és szabályai. Az Európai Unióban az adópolitika kialakítása tagállami hatáskörbe tartozik, az unió csak akkor él adóharmonizációs eszközével, ha adózással kapcsolatos egyes kérdések nem oldhatók meg tagállami szinten. Az adóharmonizáció az indirekt adózás terén a legteljesebb körű, míg a közvetlen adók tekintetében főként ajánlásokra és az Európai Bíróság esetjogára lehet támaszkodni, tehát az országok viszonylag szabadon alakíthatják közvetlen adózási szabályaikat a négy alapszabadság, vagyis a személyek, a szolgáltatások, a tôke és az áruk szabad mozgásának korlátozása nélkül.

Az unió adóharmonizációs tevékenysége keretében megfogalmazott általános elvárások és tendenciák, melyek főként a kettős adóztatás elkerülésére és az adózási szabályozások egységesítésére irányulnak, hatással vannak az önkormányzati szektor adórendszerére is. Az Európai Unió a Helyi Önkormányzatok Európai Chartájában (European Charter of Local Self-Government) biztosítja a tagországokban a helyi és a regionális hatóságok jogait, autonómiáját, melyek közül kiemelendő a helyi adók kivetésének joga. Ez a legfontosabb specifikus nemzetközi szintű jogi szabályozás Európában, ami a helyi önkormányzást szabályozza. A valamennyi tagállam által kötelezőnek elismert egyezmény 1985. október 15-én kelt Strasbourgban. E charta értelmében a helyi önkormányzatok maguk határozhatják meg a helyi szükségletekhez mérten, a hatékony múködés érdekében a saját belső igazgatási struktúrájukat. A charta 9. cikkében találhatók a helyi önkormányzatok finanszírozására vonatkozó rendelkezések, közöttük a három legfontosabb alapelv:

1. A bevételi oldal elve: a helyi önkormányzatok saját pénzügyi forrásokra jogosultak, amelyekkel hatáskörükön belül szabadon rendelkezhetnek.

2. A kiadási oldal elve: fontos, hogy a bevételek legalább egy részének felhasználásáról szabadon rendelkezhessenek.

3. A helyi adóhatalom elve: a források legalább egy részének olyan helyi adó- és díbevételekből kell állnia, melyekre e helyi szerveknek hatásköre van, vagyis saját maguk dönthetnek azok mértékéről (Erdős 2008).

\section{A központi és a helyi adórendszer kapcsolata, a helyi adórend- szerek típusai}

Az önkormányzati rendszer két legfontosabb funkciója a forrásteremtés és a forrásallokáció. A forrásteremtés szolgál alapul a közfeladatok finanszírozásához. Az önkormányzati bevételek lehetnek saját bevételek, felsőbb szintű kormányzati szektortól származó támogatások és kölcsönforrások. A saját bevételekhez tartoznak 
a helyi és a megosztott adók. A többszintủ kormányzati rendszerekben a helyi igazgatás a központi törvényhozástól függ, a kormányzat által szabott keretek rugalmassága vagy szilárdsága meghatározza a helyi költségvetési rendszer alakulását. A helyi adóbevételek hozzájárulnak az önkormányzati autonómia fenntartásához, mivel ezek révén a helyi költségvetés kevésbé érzékeny a felsőbb kormányzati szintek költségvetésének időbeli változékonyságára. A kormányzati szintek közötti vertikális közpénzügyi egyensúlyt a helyi adók rendszerének működtetése mellett a központi adók helyi hatóságokkal történó megosztása biztosítja (Vigvári 2011), ugyanis szinte elengedhetetlen bizonyos adók adóztatási jogának alsóbb kormányzati szintre delegálása.

Európa országaiban az államrendszer és a közigazgatás egyedi fejlődése következtében az egyes országokban eltérően jöttek létre a helyi önkormányzatok, ami különböző rendszertípusok kialakulását okozta. A jóléti állam három típusát (liberális, konzervatív és szociáldemokrata) különböztethetjük meg (EspingAndersen 1990). A három típus közötti különbség az újraelosztás mértékéből adódik: míg a liberális típusú országokban (például Egyesült Államok, Kanada) alacsony, a konzervatív típusúakban (például Franciaország, Németország) közepes, addig a szociáldemokrata típusú jóléti államokban (skandináv országok) magas.

Egy másik csoportosítás alapján az európai adórendszerek alapvetően kétféle (angolszász és kontinentális) adóztatási modell jellemzőit hordozzák magukban. Az angolszász típusú rendszerekre a helyi igazgatás jelentős mértékú megosztottsága jellemző, a helyi közfeladatok köre viszonylag szűk. A települési önkormányzatok felett a körzeti és a megyei önkormányzatok múködnek, melyek szélesebb felelősségi körrel rendelkeznek. A kontinentális modellen belül több altípus is megkülönböztethető: a skandináv, a francia, a vegyes rendszerek és a germán modell.

A skandináv modellben a nagyméretű helyi önkormányzatok széles felelősségi és hatásköre jellemző. Ide tartozik többek között Svédország és Dánia. A kisebb településeket összevonták, hogy a mérethatékony egységek létrehozásával megpróbálják elkerülni a települések nagyságrendbeli eltéréséből adódó problémákat. A magas lakosságszámú települési önkormányzatok az összes alapfeladatot ellátják. A megye nyújtja a középfokú szolgáltatásokat, főként az egészségügy, a közoktatás és a tömegközlekedés területén.

A francia modellre a kisközséges önkormányzati rendszer jellemző, melyben átfogó felelősség érvényesül, a helyi önkormányzatok a helyi közügyek és feladatok széles körét látják el. Itt is kialakultak regionális szintek, az alapfeladatok a megyei önkormányzatokhoz, a középszintű feladatok pedig a regionális önkormányzatokhoz tartoznak. Ezek mellett a társulási rendszer is színesíti a közigazgatási struktúrát. A francia modell jellemző Franciaországon kívül a dél-európai országokra, mint Spanyolország, Olaszország és Portugália.

Területi Statisztika, 2016, 56(3): 320-345; DOI: 10.15196/TS560304 
A harmadik kontinentális típusú önkormányzati rendszernek a vegyes rendszerek tekinthetők, ahová legfőképp a volt rendszerváltó közép-európai országok tartoznak (Kara-Kökényesi 2007). Esetükben a felsorolt rendszerek jellemzői keverednek. Például a magyar önkormányzati rendszer a francia típusú struktúra és a skandináv feladatmegosztási rendszer kombinációja.

Szükséges még megemlíteni a germán típusú közigazgatási rendszert, mely Németországban és Ausztriában múködik. Itt a tartományok (Land, Bundesland) magas fokú önállósága, emellett az egységes önkormányzati szabályozás hiánya jellemzó, és a tagállami rendszeren belül községi, járási és kerületi önkormányzati szintek múködnek.

Összességében megállapítható, hogy az angolszász modell országaiban a központi hatalom állapítja meg az önkormányzati jogköröket és feladatokat, kezdetben az önkormányzatok szigorúan csak a törvényhozó által meghatározott feladatokat láthatták el. Ezekben az államokban a helyi önkormányzatoknak az infrastrukturális és a humán jellegủ közszolgáltatások ellátása az elsődleges feladatuk. A kontinentális modell országaiban a helyi önkormányzatok a közszolgáltatások biztosítása és szervezése mellett közhatalmi funkciót is betöltenek, azaz hatósági jogalkotási és jogalkalmazási hatáskörük is van. A kötelező feladatok mellett általában az önkormányzatok át is vállalhatnak más szervektől alternatív feladatokat, illetve szabadon vállalható feladatokat is elláthatnak.

\section{A helyi adók sajátosságai néhány európai országban}

A helyi adózás tekintetében az európai gyakorlat rendkívül sokszínú. Az eltérő történelmi, társadalmi és kulturális fejlődés következtében az országok közigazgatási rendszereiben, fiskális politikájában különbségek mutatkoznak. Ennek ellenére feltárhatók alapvető hasonlóságok is. Európa országaiban a fiskális decentralizáció mértékét tekintve jelentősebb eltérések is vannak, azonban minden egyes országban a központi kormány realizálja az adóbevételek szignifikáns hányadát (1. ábra). Azokban az országokban, ahol a regionális kormányzati szint a közigazgatási struktúrában fontos szerepet tölt be (például Németországban), az adóbevételek nagyobb mértékben oszlanak meg a kormányzati szegmensek között. 


\section{Az adóbevételek megoszlása a kormányzati szintek között, 2013}

1. ábra

Distribution of tax revenues between different levels of government, 2013

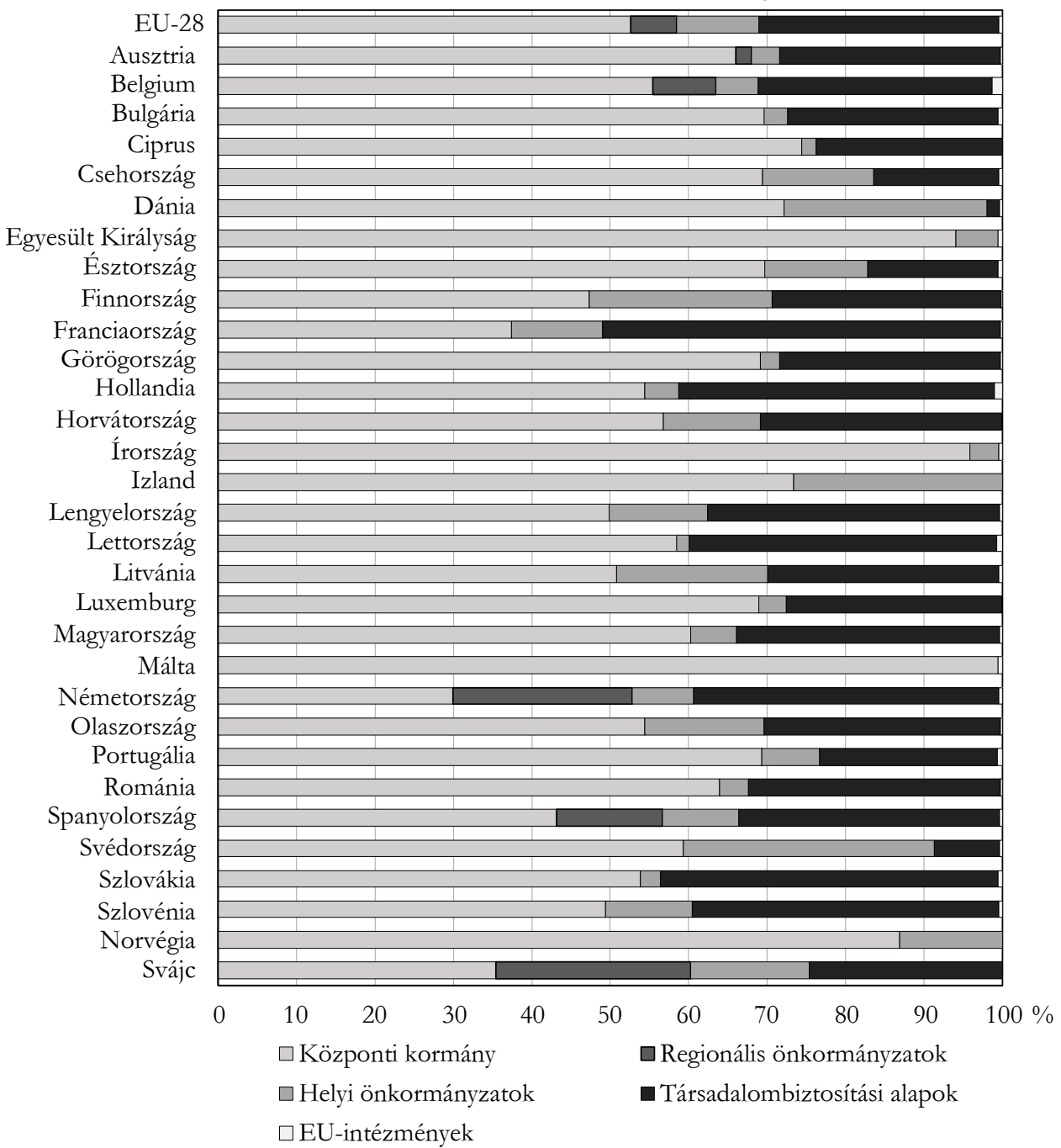

Forrás: szerző saját szerkesztése Eurostat-adatok (http://ec.europa.eu/eurostat/en/web/products-datasets//GOV_10A_TAXAG) alapján.

A helyi önkormányzati szint bevételi struktúráját tekintve azonban már jelentősebbek a különbségek az egyes országok között annak tükrében, hogy a helyi szervek mennyi adóbevételt realizálnak. A helyi önkormányzati szinten az adóbevételeknek az összes helyi bevételen belüli arányát a 2 . ábra szemlélteti. (A pontosság kedvéért azonban fontos megjegyezni, hogy az ábrán látható adóbevételi ráták nem csupán a helyi adókból származó bevételeket tartalmazzák,

Területi Statisztika, 2016, 56(3): 320-345; DOI: 10.15196/TS560304 
hanem az állam által megosztott adókból származó forrásokat is.) A helyi önkormányzatok Görögországban és Hollandiában, valamint az Egyesült Királyságban és Írországban részesednek legalacsonyabb arányban az adóbevételekből. Ezzel ellentétben a legtöbb adó jellegű bevételt Izland, Ausztria és Svédország helyi önkormányzatai realizálják. Az ábrán szereplő hányadokból arra következtethetünk, hogy míg az utóbbi országok önkormányzatai nagyobb önállósággal rendelkeznek költségvetésük bevételi oldalának meghatározásakor, addig a görög, a holland, az angol és az ír helyi önkormányzatok rendkívül támogatásfüggők, hiszen bevételeik nagy része az állami transzferekből, támogatásokból származik.

2. ábra

\section{Az adóbevételek aránya a helyi bevételekből, 2013}

Share of tax revenues in total local revenues, 2013

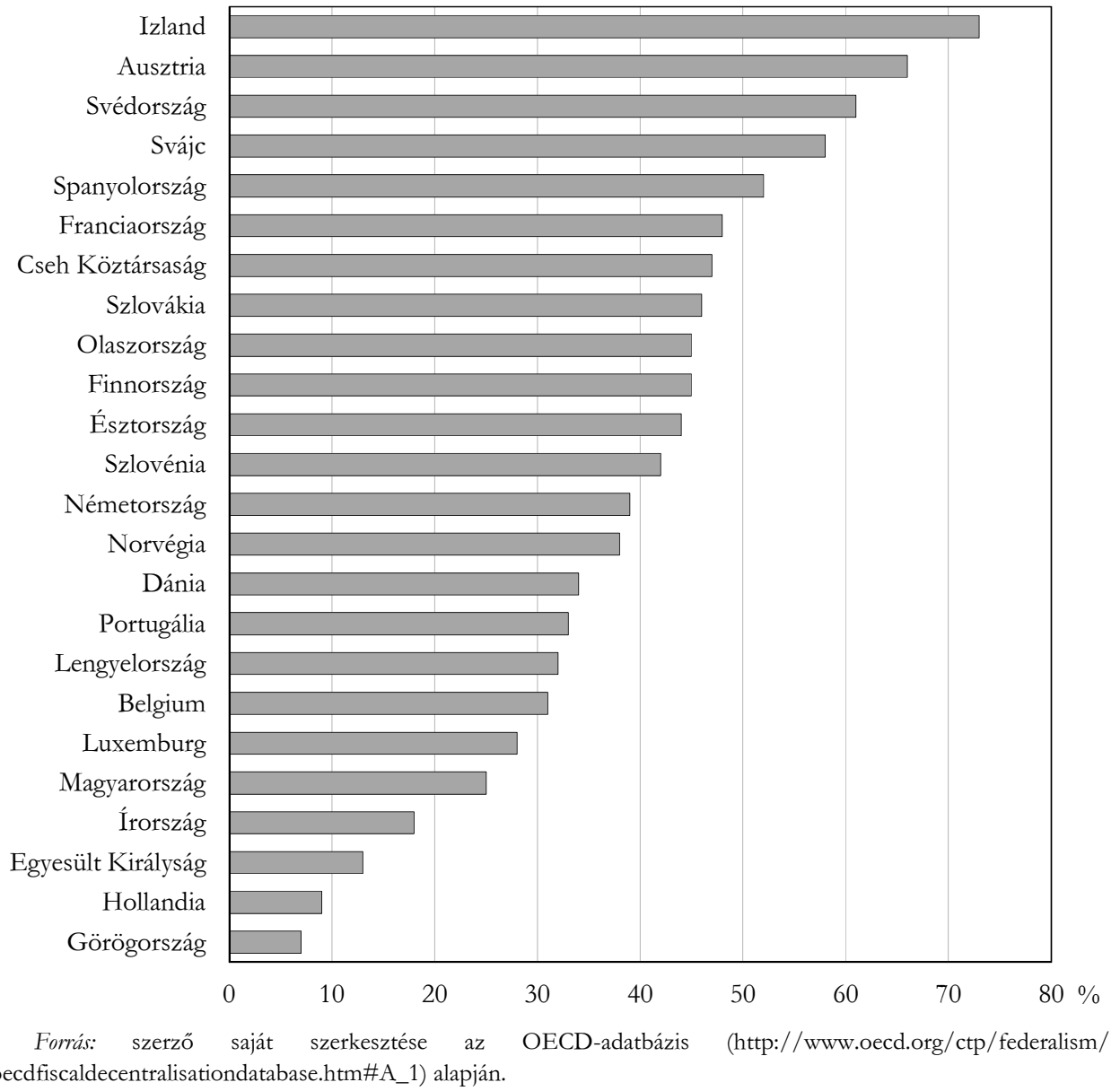

Területi Statisztika, 2016, 56(3): 320-345; DOI: 10.15196/TS560304 
Az európai országok egy részében az immobil adóalapra kivetett helyi adók dominálnak, melyek közé a vagyoni típusú adókat sorolhatjuk (1. táblázat). Annak ellenére, hogy ezek az adónemek háttérbe szorulóban vannak, számos országban mégis a helyi önkormányzati bevételek jelentős hányadát biztosítják, mint például az Egyesült Királyságban, Franciaországban, Spanyolországban és Lengyelországban. Az építmény-, a telek-, illetve a földadó mellett előfordul, hogy több vagyonelemre is kiterjed az adó hatálya, például Norvégiában, ahol a magánszemély egy bizonyos küszöbérték felett a nettó vagyona után az állami vagyonadó mellett helyi szinten is adót köteles fizetni. Több országban is érvényesül, hogy a vagyoni típusú adókat csak a természetes személyekre vagy csak a vállalkozási szférára vetik ki: az Egyesült Királyságban csak lakossági ingatlanadó van, míg Norvégiában az ingatlanadó csupán a vállalkozásokra terjed ki. Mindenesetre megállapíthatjuk, hogy az ingatlanadóból akkor származik számottevő bevétel, ha az adó mind a lakossági, mind a vállalkozási szférát felöleli. Az ingatlanadózás tekintetében számos országban, főleg NyugatEurópában ingatlankatasztert, vagyis államilag felértékelt ingatlan-nyilvántartást vezetnek. Több országban egy régebbi értékelést vesznek alapul, mint például az Egyesült Királyságban vagy Németországban, ezzel szemben Hollandiában az ingatlanokat minden évben újraértékelik. Érdekesség továbbá, hogy Spanyolországban és Portugáliában a helyi adórendszer eltérő adómértékek elôirásával különbséget tesz vidéki és városi ingatlan között.

A vagyoni típusú helyi adóztatás mellett több országban is elterjedt a mobil adóalapok adóztatása helyi szinten, beleértve a személyi jövedelemadót és a vállalkozások nyereségadóját is. A skandináv országokban (például Svédországban, Norvégiában, Dániában), valamint Szlovákiában, Lettországban, Észtországban is a mobil adóalappal alkalmazott helyi adókból származó bevételek jelentik a helyi adóbevételek legnagyobb hányadát. Az országok jelentős részében a személyi jövedelemadóból és a vállalkozási nyereségadóból származó bevételeket az egyes kormányzati szintek között megosztják, méghozzá úgy, hogy a helyi szervek pótadó formájában vetnek ki egy adómértéket az adóalapra.

Az eddig említett főbb helyi adónemeken kívül találkozhatunk szélesebb körben elterjedt adónemekkel is, mint például a gépjárműadó, az ebadó vagy az idegenforgalmi adó, de előfordulnak olyan kisebb helyi adónemek is, mint a szemétszállítási adó (például Olaszország, Franciaország), szórakozási adó (például Németország, Svájc), közterület-használati adó (például Szlovákia, Horvátország), háztartási adó (Svájc), lakóhelyi adó (Franciaország).

Területi Statisztika, 2016, 56(3): 320-345; DOI: 10.15196/TS560304 


\section{Az egyes országokban alkalmazott föbb helyi adónemek, 2015}

Main local taxes in selected European countries, 2015

\begin{tabular}{|c|c|}
\hline Ország & Helyi adónemek \\
\hline Ausztria & Ingatlanadó, kommunális adó \\
\hline Dánia & Helyi jövedelemadó, földadó, vállalkozási vagyonadó \\
\hline Egyesült Királyság & Lakossági ingatlanadó \\
\hline Észtország & Földadó \\
\hline Finnország & Helyi jövedelemadó, ingatlanadó \\
\hline Franciaország & $\begin{array}{l}\text { Ingatlanadó, lakóhelyi adó, szemétszállítási adó, közlekedési adó, } \\
\text { áramadó, városfejlesztési adó }\end{array}$ \\
\hline Hollandia & ingatlanadó, ebadó, földadó, idegenforgalmi adó \\
\hline Írország & Ingatlanadó \\
\hline Izland & Helyi jövedelemadó, ingatlanadó \\
\hline Lengyelország & $\begin{array}{l}\text { Ingatlanadó, mezőgazdasági adó, gépjárműadó buszokra és } \\
\text { tehergépjármûvekre, erdészeti adó, ebadó }\end{array}$ \\
\hline Luxemburg & Vállalkozási nyereségadó pótadója, ingatlanadó \\
\hline Magyarország & $\begin{array}{l}\text { Iparűzési adó, ingatlanadó, idegenforgalmi adó, kommunális adó, } \\
\text { települési adó }\end{array}$ \\
\hline Németország & Iparűzési adó, ingatlanadó, helyi fogyasztási és fényűzési adók \\
\hline Norvégia & Helyi jövedelemadó, vagyonadó, vállalkozási ingatlanadó \\
\hline Olaszország & $\begin{array}{l}\text { Vagyonadó, jövedelemadóra pótadó, helyi szolgáltatási adó, } \\
\text { szemétszállítási adó, helyi reklámadó, közterület-használati adó }\end{array}$ \\
\hline Portugália & Helyi jövedelemadó, vagyonadó, vállalkozási nyereségadóra pótadó \\
\hline Spanyolország & Ingatlanadó, iparűzési adó, gépjárműadó, építési adó, értéknövekedési adó \\
\hline Svájc & $\begin{array}{l}\text { Jövedelmi és vagyonadó, fejadó/háztartási adó, társasági adóra pótadó, } \\
\text { öröklési és ajándékozási adó, lottónyeremények adója, ingatlanadó, } \\
\text { ingatlan-átruházási adó, ebadó, szórakozási adó }\end{array}$ \\
\hline Svédország & Helyi jövedelemadó \\
\hline Szlovákia & $\begin{array}{l}\text { Ingatlanadó, gépjárműadó, ebadó, idegenforgalmi szállásadó, közterület- } \\
\text { használati adó, árusító automaták adója, nukleáris létesítmények adója }\end{array}$ \\
\hline
\end{tabular}

Forrás: szerző saját szerkesztése az országok helyi önkormányzati törvényei és a Deloitte és a PwC online adatbázisai alapján.

Területi Statisztika, 2016, 56(3): 320-345; DOI: 10.15196/TS560304 
Az európai helyi adórendszerek között abban a tekintetben is felfedezhetők eltérések, hogy a helyi önkormányzatoknak milyen fokú autonómiája van, ugyanis az országok között különbségek mutatkoznak a helyi szervekre ruházott döntési szabadságok terén. E döntési jogok kiterjednek a helyi adóztatás minden részletére, közöttük arra is, hogy milyen adónemeket vethetnek ki egyáltalán, azok kötelező jellegúek-e, megválaszthatják-e az adó alapját, tárgyát, mértékét, az adó alóli mentességek körét, az adókedvezményeket, valamint a befolyt bevételeket szabadon felhasználhatják-e.

\section{Helyi adórendszer Angliában}

Az Egyesült Királyság sajátosan berendezett állam, magában foglalja Angliát, Skóciát, Walest és Észak-Írországot. Anglia önkormányzati rendszeréról a westminsteri parlament rendelkezik, amely a szabályozási hatáskört - devolúció útján - átengedte a skót, a walesi és az észak-ír területeknek, tehát azok saját parlamentjeinek hatáskörébe helyezték az önkormányzati szabályozást. A továbbiakban csak Anglia helyi adórendszerét vizsgáljuk.

Az angol helyi önkormányzati rendszer három fő területre tagolódik: nagyvárosi terület (metropolitan area), grófsági terület (shire area) és fövárosi terület (capital area). A három fó területen belül múködnek a helyi önkormányzatok és ezek mellett ún. egycélú önkormányzatok is. A helyi önkormányzatok felelőssége a humán jellegú (például oktatás) és infrastrukturális közfeladatokra terjed ki. A feladatok viszonylag széles körűek, amit az is alátámaszt, hogy a 2013-2014-es költségvetési időszakban ${ }^{1}$ a kormányzati szektor összes kiadásának 23\%-át költötték el az angol önkormányzatok. ${ }^{2}$

1993. április 1-jétől lépett hatályba a jelenlegi helyi adó, a tanácsi adó (council tax), mely az egyedüli helyi adónem Angliában. A tanácsi adó vagyoni típusú adó, melynek tárgya a lakás (dwelling). Az adó alanya főszabály szerint az a 18. életévét betöltött természetes személy, aki határozatlan idôre szóló korlátlan joga alapján a lakásban él. A tanácsi adó alapja a központi adóhatóság (Valuation Office Agency - VOA) szervezeti egysége által 1991-ben megállapított forgalmi érték. ${ }^{3}$ A szervezet által összeállított jegyzék alapján kell a helyi önkormányzatoknak a tanácsi adót kivetniük. Az adó mértékét tehát a helyi önkormányzat állapítja meg tételesen a helyi önkormányzatokról szóló törvény (Local Government Finance Act 1992) által meghatározott $\mathrm{A}-\mathrm{H}$ adósáv használatával (2. táblázat).

\footnotetext{
${ }^{1} \mathrm{Az}$ angol adóév április 6-tól következő év április 5-ig tart.

${ }^{2}$ Department for Communities and Local Government (2015) 6. p.

${ }^{3}$ Local Government Finance Act (1992) 21. \ (1)-(2).
}

Területi Statisztika, 2016, 56(3): 320-345; DOI: 10.15196/TS560304 
Tanácsi adósávok Angliában, 2014

2. táblázat

Council tax bands, 2014

\begin{tabular}{c|l|c|c|c}
\hline Sáv & $\begin{array}{c}\text { A lakás értéke } \\
\text { 1991. április 1-jén, font }\end{array}$ & $\begin{array}{c}\text { Adótétel } \\
\text { aránya }\end{array}$ & $\begin{array}{c}\text { A lakások száma } \\
\text { 2014. szeptember } \\
8 \text {-án }\end{array}$ & $\begin{array}{c}\text { A lakások aránya, } \\
\%\end{array}$ \\
\hline A & 40000 alatt & $6 / 9$ & 5784 & 25 \\
B & $40001-52000$ & $7 / 9$ & 4610 & 20 \\
C & $52001-68000$ & $8 / 9$ & 5112 & 22 \\
D & $68001-88000$ & $9 / 9$ & 3610 & 15 \\
E & $88001-120000$ & $11 / 9$ & 2220 & 9 \\
F & $120001-160000$ & $13 / 9$ & 1173 & 5 \\
G & $160001-320000$ & $15 / 9$ & 822 & 3 \\
H & 320000 felett & $18 / 9$ & 136 & 1
\end{tabular}

Forrás: szerző saját szerkesztése a Local Government Finance Act (1992) 5. \(1)-(2) és a Local Government Financial Statistics England (2015) alapján.

Az önkormányzatoknak a tanácsi adó kivetésénél szem előtt kell tartaniuk a költségvetésük alakulását, tehát figyelembe kell venniük, hogy mennyi bevételre lesz szükségük. Az adómértéknek nincs törvényi határa, az önkormányzatoknak a D-sávot úgy kell pozícionálniuk, hogy a helyi adóbevétel fedezze a kiadásaik azon részét, melyre a külső források nem elegendőek. Az adó mértékét azonban nem emelhetik felelőtlenül, ugyanis az angol önkormányzati törvény (Localism Act 2011) bevezetésével a helyi választópolgárok kezébe került a helyi adóemelések feletti kontroll. Kiugróan magas helyi adóemelés ${ }^{4}$ esetén népszavazást kell tartani arról, hogy a lakosság elveti vagy támogatja-e az adóemelést.

A D-sáv adótételének átlagos értéke a 2015-2016-os költségvetési évben 1484 font, ami a tanácsi adó bevezetése óta eltelt 20 évben (a kezdeti 568 fontról) több mint kétszeresére emelkedett.

\footnotetext{
${ }^{4}$ Hogy mekkora mértékű emelés minősül kiugróan magasnak, azt az önkormányzati miniszter határozza meg minden évben. A 2015-2016-os adóévre a D-sávra vonatkozóan a 2\% feletti előző évhez viszonyított adóemelést állapították meg kiugróan magasnak. A túlzott mértékű adóemelések visszaszorítása érdekében a kormány kiegészítő támogatást nyújt azoknak a helyi önkormányzatoknak, amelyek „befagyasztják” a tanácsi adó mértékét. A költségvetési támogatásra (council tax freezue grant) fordított összeg 148 millió font volt a 2014-2015-ös költségvetési évben.
} 
3. táblázat

A tanácsi adóbevétel súlya a helyi önkormányzatok bevételeiben, Angliában

Proportion of council tax revenues in local government revenues in England

\begin{tabular}{c|c|c|c|c|c|c}
\hline Adóbevétel & $2008-2009$ & $2009-2010$ & $2010-2011$ & $2011-2012$ & $2012-2013$ & $2013-2014$ \\
\hline $\begin{array}{c}\text { Összes helyi bevétel, } \\
\text { millió font }\end{array}$ & 153820 & 162257 & 165204 & 159694 & 155306 & 157554 \\
$\begin{array}{c}\text { Tanácsi adóbevétel, } \\
\text { millió font }\end{array}$ & 24759 & 25633 & 26254 & 26451 & 26715 & 23361 \\
$\begin{array}{c}\text { A tanácsi adó aránya } \\
\text { az összes helyi } \\
\text { bevételben, \% }\end{array}$ & 16,10 & 15,80 & 15,89 & 16,56 & 17,20 & 14,83
\end{tabular}

Forrás: szerző saját szerkesztése a Department for Communities and Local Government (2015) alapján.

A tanácsi adóbevételek az összes angol kormányzati adóbevételnek 5\%-át teszik ki. ${ }^{5}$ A helyi önkormányzatok bevételének átlagosan 16\%-a származik a tanácsi adóból (3. táblázat). A helyi adóbevétel az összes helyi bevételen belüli viszonylag alacsony arányából következik, hogy az angol helyi önkormányzatok költségvetése jelentős mértékben támogatásfüggő.

\section{Helyi adórendszer Németországban}

Németországban az alaptörvény (Grundgesetz) biztosítja a tartományok jogait és hatásköreit. Minden tartománynak külön választott parlamentje működik, saját alkotmánnyal rendelkeznek, a tartományi törvényhozás alá rendelt ügyekben saját törvényeket és rendeleteket alkothatnak, de törvényhozásuk során a szövetségi törvények kereteihez kell igazodniuk. Az egyes tartományokon belül találhatók a járások ${ }^{6}$ (Landkreise), amelyek alá a legtöbb település (Gemeinde) tartozik. Emellett mûködnek járásokhoz nem tartozó városok is (Kreisfreie Städte).

Az önkormányzatok adóbevételeire vonatkozóan az alaptörvény a legfőbb jogforrás, amely rendelkezik arról, hogy a jövedelemadóból (Einkommensteuer) és a forgalmi adóból (Umsatzsteuer) a tartományok útján részesednie kell a települési önkormányzatoknak. Annak ellenére, hogy e két adónem szabályozására nincs semmilyen hatáskörük, a megosztott adókból származó bevételeik kiszámítható és fontos részét képezik a költségvetésüknek.

Az alaptörvény 106. \ (6) bekezdésében foglaltak alapján a helyi önkormányzatokat illetik meg az ingatlanadóból (Grundsteuer) és az iparűzési adóból

\footnotetext{
5 Department for Communities and Local Government (2015) p. 7.

${ }^{6}$ A szakirodalomban a járási önkormányzatokat több helyen is megyei önkormányzatokként tüntetik fel, nemcsak a magyar, hanem az angol szakirodalom is használja mindkét fordítást.
}

Területi Statisztika, 2016, 56(3): 320-345; DOI: 10.15196/TS560304 
(Gewerbestener) származó bevételek, csakúgy, mint a helyi fogyasztási és fényűzési adók (Örtliche Verbrauch-und Aufwandsteuern). Rendelkezik továbbá arról is, hogy az iparüzési adóból a tartományok és a szövetségi kormány is részesedik. Külön bekezdésben rögzíti az alaptörvény, hogy az iparűzési és az ingatlanadó mértékérôl a törvényi keretek között a helyi önkormányzatok döntenek.

Míg az iparűzési és az ingatlanadó múködését szövetségi törvények szabják meg, és - ezek tekintetében zárt listás adómegállapítási módszert alkalmazva - a helyi szervek csak az adómértékről dönthetnek, addig a helyi fogyasztási és fényúzési adók szabályozása teljes mértékben a tartományok hatáskörébe tartozik. Ide olyan kisebb adónemek sorolhatók, mint az ebadó (Hundesteuer), a vadászati és halászati adó (Jagdund Fischereisteuer), az italmérési adó (Schankerlaubnissteuer), a szórakozási adó (Vergnügungsteuer), a második lakás adója (Zweitwohnungsteuer).7

4. táblázat

\section{Az adóbevételek összes bevételen belüli aránya az egyes államigazgatási szinteken, Németországban}

Proportion of tax revenues within total revenues at levels of public administration in Germany

\begin{tabular}{l|c|c|c|c|c}
\multicolumn{1}{c}{ Államigazgatási szint } & \multicolumn{1}{c}{2008} & 2009 & 2010 & 2011 & 2012 \\
\hline Szövetségi & 93,99 & 93,51 & 93,63 & 93,17 & 94,43 \\
Tartományi & 70,13 & 66,97 & 64,66 & 65,09 & 66,68 \\
Helyi & 40,30 & 36,98 & 36,89 & 38,12 & 39,41 \\
$\quad \begin{array}{l}\text { Forrás: szerző saját szerkesztése az OECD adatbázisa } \quad \text { (http://www.oecd.org/ctp/federalism/ } \\
\text { table16_tax_revenue_na-log_rev_internal.xls) alapján. }\end{array}$
\end{tabular}

A német államigazgatási szintek adóbevételeinek az összes bevételükön belüli arányát bemutató 4 . táblázat szerint 2012-ben a helyi önkormányzatok bevételeinek közel 40\%-át tették ki a helyi adóbevételek, azaz jelentős szerepet töltöttek be az önkormányzati költségvetésben.

Az iparűzési adóból és az ingatlanadóból származó bevételek 2014-ben az összes önkormányzati adóbevételnek körülbelül 65\%-át tették ki (3. ábra). Az önkormányzatok összesen 86500 millió euró adóbevételt realizáltak, melyből 56500 millió euró származott iparűzési és ingatlanadó-bevételből. Utóbbi több mint 20\%-ot képvisel a helyi adóbevételeken belül. 2010 és 2014 között a legmeghatározóbb helyi adónem pedig az iparűzési adó volt, ami a helyi adóbevételek 75-78\%-át tette ki.

${ }^{7}$ Bundesministerium der Finanzen (2013).

Területi Statisztika, 2016, 56(3): 320-345; DOI: 10.15196/TS560304 


\section{A német helyi önkormányzatok adóbevételeinek alakulása}

German local government tax revenues

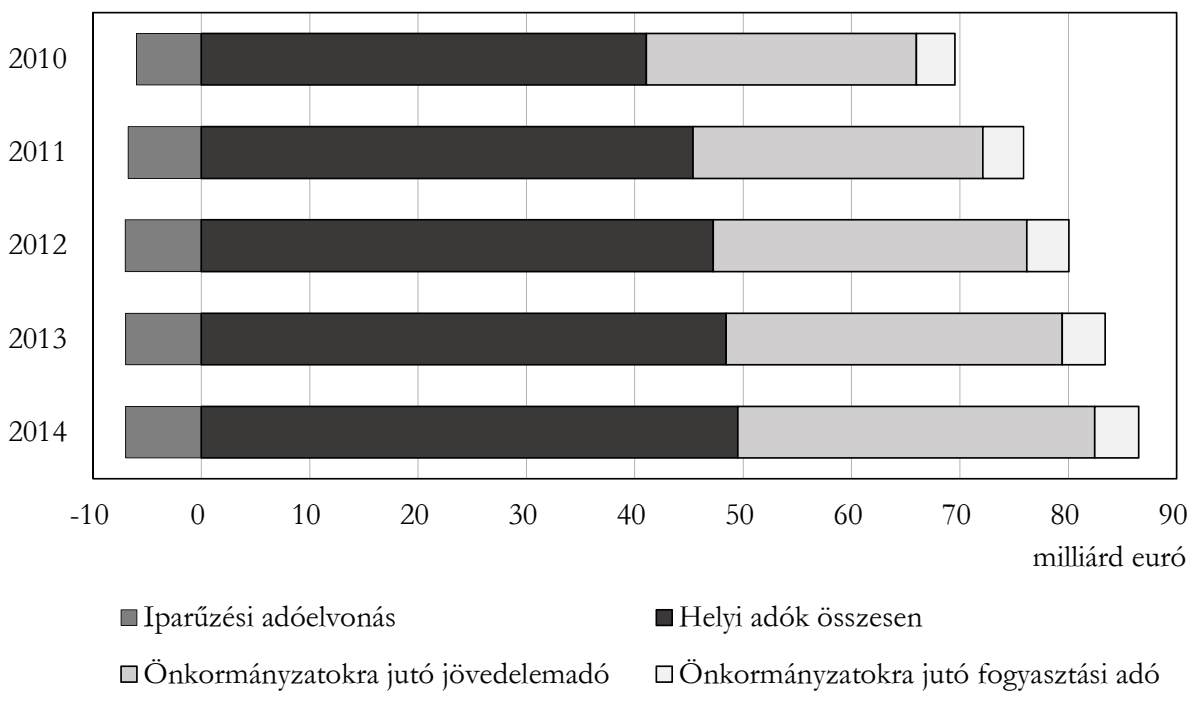

Forrás: szerző saját szerkesztése a Német Statisztikai Hivatal adatai (Statistisches Bundesamt, 2015) alapján.

Az iparűzésiadó-elvonás, amit a tartományok és a szövetségi kormány költségvetésébe csoportosítottak át, 7 milliárd euró volt 2014-ben. Emellett az önkormányzatokra osztott jövedelemadó és fogyasztási adó együttesen a helyi adóbevételek körülbelül 40\%-át tette ki, tehát jelentőségük korántsem elhanyagolható.

\section{Helyi adórendszer Spanyolországban}

Az 1978-as spanyol alkotmány (Constitución Española) 137. \-a alapján a spanyol állam települési önkormányzatokra (municipios), tartományokra (provincias) és autonóm közösségekre (Comunidades Autónomas) tagolódik, melyek mindegyike önkormányzáshoz való joggal bír. 50 tartomány és összesen 8117 települési önkormányzat, valamint 17 tagállamként múködő autonóm közösség található Spanyolországban (OECD 2015).

A három fő bevételi forrást az autonóm közösségek költségvetésében a központi költségvetési támogatások, a saját bevételek és az Európai Unió által biztosított támogatások jelentik. Az autonóm közösségek saját pénzforrásai között kiemelt szerepet kapnak a saját adók, illetékek és különadók. A tartományok, amelyek múködésüket tekintve a magyar megyékhez hasonlatosak, önálló helyi adóval nem rendelkeznek, hanem központi támogatásokat kapnak. A települési önkormányzatok

Területi Statisztika, 2016, 56(3): 320-345; DOI: 10.15196/TS560304 
bevételei a helyi adókból, központi költségvetési támogatásokból, projekt támogatásokból és bírságokból, díjbevételekből állnak.

A 2008 és 2012 közötti adatokat vizsgálva megállapítható, hogy a települési önkormányzatok bevételei között fontos szerepet töltenek be az adóbevételek, ugyanis a helyi önkormányzati bevételeknek körülbelül felét az adóbevételek teszik ki, míg regionális szinten ez az arány némiképp magasabb, 2012-ben már 65\% volt az összes bevételen belül.

\section{Az adóbevételek összes bevételen belüli aránya az egyes államigazgatási szinteken, Spanyolországban}

5. táblázat

Proportion of tax revenues within total revenues at levels of public administration in Spain

\begin{tabular}{l|r|r|r|r|c}
\hline \multicolumn{1}{c|}{ Államigazgatási szint } & \multicolumn{1}{c|}{2008} & \multicolumn{1}{c|}{2009} & \multicolumn{1}{c|}{2010} & \multicolumn{1}{c}{2011} & 2012 \\
\hline Központi & 90,94 & 91,08 & 89,71 & 84,17 & 77,87 \\
Regionális & 52,27 & 47,58 & 43,43 & 58,25 & 65,21 \\
Települési & 49,24 & 43,51 & 46,20 & 49,49 & 51,67
\end{tabular}

Forrás: szerző saját szerkesztése az OECD adatai (www.oecd.org/ctp/federalism/table16_tax_revenue_nalog_rev_internal.xls) alapján.

Spanyolországban összesen 5 helyi adónemet vethetnek ki a települési önkormányzatok. A helyi adókról szóló törvény (RDLeg. 2/2004) a következő helyi adónemeket intézményesítette:

- Kötelező kiróni az ingatlanadót (Impuesto sobre bienes inmuebles - IBI), az iparűzési adót (Impuesto sobre actividades económicas - IAE) és a gépjármúadót (Impuesto sobre vehiculos de tracción mecánica - IVTM).

- Az önkormányzatok dönthetnek az építési adó (Impuesto sobre construcciones, instalaciones y obras - ICIO) és az értéknövekedési adó bevezetéséről (Impuesto sobre incremento de valor de los terrenos de naturaleza urbana - IIVTNU).

A 4. ábra mutatja a helyi adónemekből származó bevételek megoszlását a 2013-as adóévben. A helyi adóbevételek 68\%-át kitevő ingatlanadó volt a legjelentősebb helyi adónem. Ezt követte a gépjármúadó a helyi adóbevételekből való 12\%-os részesedéssel. A legkisebb részaránya (mindössze 3\%) az építési adónak volt.

A helyi önkormányzatok által megszerzett helyi adóbevételek összege növekvő tendenciát mutat. A 4. ábra szerint az egyes helyi adónemekből származó bevételek nagyságrendjében 2007 és 2013 között folyamatos különbség mutatkozik, illetve az ingatlanadó dominanciája egyre erőteljesebbé vált. 


\section{Spanyol helyi adóbevételek adónemenként}

Spanish local tax revenues by items



Forrás: szerző saját szerkesztése a Spanyol Pénzügyi és Közigazgatási Minisztérium által közzétett adatok (Ministerio De Hacienda Y Administraciones Públicas 2013, 2012, 2011, 2010 és 2009) alapján.

\section{Helyi adórendszer Svédországban}

Svédország alkotmányos monarchia, parlamentáris rendszerrel és fejlett gazdasággal. A Svéd Alkotmányban (Grundlagar) fektették le az önkormányzás alapjait. Az Alkotmány négy külön alaptörvényből áll ${ }^{8}$, melyek közül a Kormányzati Okirat 14. fejezete rendelkezik a helyi szervekről, miszerint a választott helyi (települési) és megyei testületek felelnek a helyi és regionális önkormányzásért, továbbá felelősek a közszolgáltatások jelentős részéért, így területi szinten kap hangsúlyt a közjólét biztosítása.

Jelenleg 290 helyi önkormányzat (kommuner) múködik az alig kevesebb mint 10 millió fős országban, valamint 21 megyei önkormányzat (landsting), beleértve Skåne, Gotland, Halland és Västra Götaland régiókat. A svéd települések átlagos lélekszáma több mint 30 ezer fó, így Svédországban találhatók a világ legnagyobb önkormányzatai. $^{9}$

A svéd jóléti államnak az egyik legfontosabb alappillérét jelentik a helyi önkormányzatok. A feladatokhoz kapcsolódóan helyi szinten a svédországi

8 A négy svéd alaptörvény: Kormányzati Okirat 1974 (regeringsformen RF), Törvény a Sikerességről 1810 (successionsordningen SO), Törvény a Sajtószabadságról 1949 (tryckfrihetsförordningen TF) és a Törvény a Szólás Szabadságáról 1991 (yttrandefribetsgrundlagen YGL).

${ }_{9}^{9}$ Swedish Association of Local Authorities and Regions (2011) p. 3.

Területi Statisztika, 2016, 56(3): 320-345; DOI: 10.15196/TS560304 
önkormányzatok az összes kormányzati kiadás 47\%-át költötték el 2013-ban, ami jelentôs arány európai összehasonlításban, ugyanis ehhez hasonlóan magas arányt csak Dániában (62\%) és Finnországban (41\%) mértek. ${ }^{10}$

A települési és a megyei önkormányzatok finanszírozását, költségvetését egységesen az önkormányzati törvény (Kommunallag) szabályozza és kihangsúlyozza, hogy az önkormányzatoknak felelős pénzügyi gazdálkodást és kiegyensúlyozott költségvetést kell fenntartaniuk. Az önkormányzati bevételek a helyi adóból, a dijbevételekból, az állami támogatásokból és egyéb bevételekból állnak.

Svédországban 1996-ban ún. jövedelemkiegyenlítő rendszert vezettek be. A kiegyenlítés célja az volt, hogy a helyi önkormányzatok mindegyikének egyenlő feltételeket teremtsenek a közfeladatok ellátásához, függetlenül az önkormányzat szervezeti felépítésétól és adóalapjától. A „Robin Hood-elv” érvényesüléseképp a bevételek egyfajta újraelosztása lehetôvé teszi az adóalap nagyságából eredő különbségek kiegyenlítését, és ezt elsődlegesen az állam finanszírozza.

A jövedelemadóról szóló törvény (Inkomstskattelag (1999:1229)) rendelkezik a nemzeti és a helyi jövedelemadóról. Az adó alapját a számviteli előírásokkal összhangban állapítják meg, figyelembe véve a törvényben meghatározott adóalapmódosító tételeket. A nemzeti és a helyi jövedelemadót a munkából és az üzleti tevékenységekből származó bevételek után együttesen vetik ki. A nemzeti jövedelemadó háromkulcsos, progresszívan növekvő.

Svéd jövedelemadókulcsok, 2015

6. táblázat

Swedish income tax rates, 2015

\begin{tabular}{l|c|c|c}
\hline \multicolumn{1}{c|}{$\begin{array}{c}\text { Adóköteles éves jövedelem, } \\
\text { korona }\end{array}$} & $\begin{array}{c}\text { Nemzeti } \\
\text { adókulcs }\end{array}$ & Helyi adókulcs & Összesen \\
\hline 430 200 alatt & 0 & $29-35$ & $29-35$ \\
$430200-616100$ & 20 & $29-35$ & $49-55$ \\
616 100 felett & 25 & $29-35$ & $54-60$
\end{tabular}

Forrás: szerző saját szerkesztése a svéd jövedelemadó törvény és a Svéd Nemzeti Adóhivatal hivatalos honlapjának adatai (www.skatteverket.se) alapján.

A helyi jövedelemadót illetően a központi kormány határozza meg az adóalapot és szedi be az adót, helyi szinten csak az adó mértékéról dönthetnek az önkormányzatok. A helyi adó tehát önkormányzatonként eltérő, mértéke az adóalany lakóhelyétől függ. 2015-ben az adó mértéke 29,19-34,70\% között mozgott ${ }^{11}$, amit minden adóalanynak a havi jövedelme után kellett fizetnie. 2015-ben a legmagasabb adómértéket (34,70\%)

${ }^{10}$ www.oecd.org/ctp/federalism/oecdfiscaldecentralisationdatabase.htm (letöltés ideje: 2016. február 15.)

11 http://www.scb.se/en_/Finding-statistics/Statistics-by-subject-area/Public-finances/Local-Governmentfinances/Local-taxes/\#c_undefined (letöltés ideje: 2015. november 18.). 
Dorotea vetette ki, míg a legalacsonyabbat (29,19\%) Vellinge. Az átlagos helyi adómérték 2015-ben 31,99\%, míg az egy főre jutó átlagos adóalap 190264 korona.

Az adómérték a helyi önkormányzatok és a megyei önkormányzatok által kivetett adómértéket is magában foglalja. A helyi önkormányzatokra az adómértéknek körülbelül 65\%-a jut, ami a 2015-ös adóévben 20,70\%-os átlagos helyi önkormányzati adómértéket jelentett, amikor is a megyei önkormányzatok 11,29\%-os átlagos adómértéket vetettek ki.

A jövedelemadó a helyi önkormányzati bevételek fontos komponense. Az adóbevételek az összes önkormányzati bevételnek 67\%-át biztosítják, míg a központi kormányzattól kapott támogatások, beleértve a jövedelemkiegyenlítő támogatásokat is, mindössze a bevételek 17\%-át tették ki, egyéb forrásokból és befektetésekből pedig a bevételek 14\%-a származott 2014-ben.

\section{A svéd önkormányzati szektor bevételei 2014-ben}

5. ábra

Revenues of Swedish local government sector, 2014

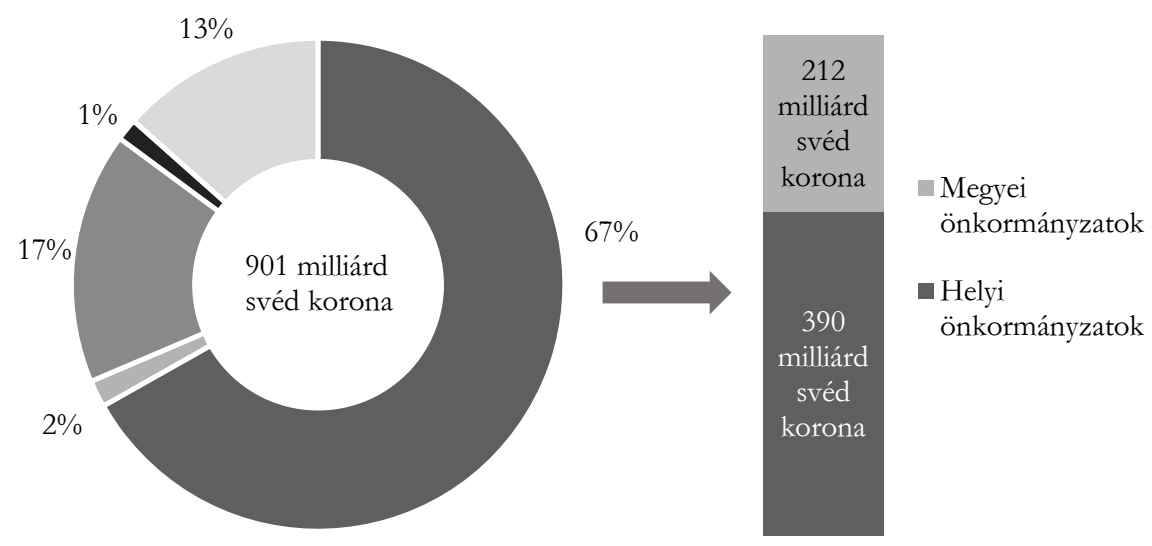

$\begin{array}{ll}\text { - Jövedelemadó } & \text { - Ingatlandíj } \\ \text { - Tőkejövedelmek } & \text { Egyéb bevételek }\end{array}$

Forrás: szerző saját szerkesztése az Ekonomistyrningsverket (2015) alapján.

Mindösszesen 602 milliárd korona jövedelemadó-bevételt realizáltak az önkormányzatok 2014-ben, melyből 390 milliárd korona a helyi önkormányzatokra jutott, 212 milliárd korona pedig a megyei önkormányzatok költségvetésébe folyt be. Az adóbevételekből az adómértékek közötti megoszlásnak megfelelően 65 és 35\%-os részaránnyal részesedik a két önkormányzati szektor.

Területi Statisztika, 2016, 56(3): 320-345; DOI: 10.15196/TS560304 
A bevételi struktúra alapján megállapítható, hogy a svéd önkormányzatok magas autonómiát élveznek a költségvetésük kialakításakor, hiszen a bevételeik legnagyobb hányadát a helyi adóbevétel teszi ki, melynek mértékéről maguk dönthetnek. Ráadásul ezáltal viszonylag csekély mértékben függnek a központi költségvetési támogatások időbeli változékonyságától.

\section{A vizsgált országok helyi adórendszereinek összehasonlítása}

\section{A közigazgatási rendszer felépítése}

A négy önkormányzati modell strukturális felépítése közötti eltérésekre az egyes országokban múködő önkormányzatok számából is következtethetünk.

A vizsgált országok lakossága és az önkormányzatok száma, 2015

Population and number of local governments in the reviewed countries, 2015

\begin{tabular}{l|r|r|r|r|r}
\hline \multirow{2}{*}{ Ország } & \multirow{2}{*}{$\begin{array}{c}\text { Lakosság, } \\
\text { ezer fő }\end{array}$} & $\begin{array}{c}\text { Önkormányzatok száma } \\
\text { települési } \\
\text { szint }\end{array}$ & $\begin{array}{c}\text { százezer } \\
\text { lakosra jutó } \\
\text { települési } \\
\text { önkormány- } \\
\text { zatok száma }\end{array}$ & $\begin{array}{c}\text { közbenső } \\
\text { szint }\end{array}$ & $\begin{array}{c}\text { regionális } \\
\text { szint }\end{array}$ \\
\hline Anglia & 54317 & 324 & 0,6 & 27 & 3 \\
Németország & 80913 & 11116 & 13,7 & 402 & 16 \\
Spanyolország & 46464 & 8117 & 17,7 & 50 & 17 \\
Svédország & 9698 & 290 & 3,0 & - & 21
\end{tabular}

Forrás: szerző saját szerkesztése az OECD adatbázisa (http://stats.oecd.org/) és a Department for Communities and Local Government (2015) alapján.

Az angolszász önkormányzati modellt múködtető Egyesült Királyság, azon belül is Anglia önkormányzati rendszerének felépítését és a helyi szinten ellátandó közfeladatok szubnacionális kormányzati szintek közötti megosztottságát hűen alátámasztja a települési önkormányzatok, valamint a közbenső és a regionális szinten múködő önkormányzatok alacsony száma. Az angolszász modellel ellentétben a germán típusú országokban jelentős számú települési önkormányzat található, amely mellett a közbenső közigazgatási szinten a járások száma is jelentős. A francia önkormányzati modell jegyeit hordozó spanyol közigazgatásban kisközséges önkormányzati rendszer múködik, a közfeladatok jelentős részének a települési önkormányzatokra való delegálásával. A százezer lakosra jutó önkormányzatok száma - a vizsgált országok közül - Spanyolországban a legmagasabb (mintegy 18) és a 
skandináv modellt képviselő, rendkívül kevés, magas lélekszámú önkormányzatot múködtető Svédországban a legalacsonyabb (mindössze 3).

\section{Az önkormányzatok bevételi struktúrája}

Az összehasonlitást OECD-adatok alapján végeztük el, melyből kifolyólag az angol helyi önkormányzatok bevételi szerkezete helyett az egész Egyesült Királyság helyi önkormányzati szektorának adatait vizsgáltuk, de ez nem torzította az elemzés eredményét, ugyanis az adatok hủen tükrözik az angolszász önkormányzati modell jellemzőit. Továbbá az adóbevételekre vonatkozó adatok nem csupán a kivetett helyi adókból befolyó bevételeket tartalmazzák, hanem a megosztott adókat is.

A közigazgatási rendszer különböző szintjei között az adóbevételek némileg eltérő arányban oszlanak meg a négy vizsgált országban. Annak ellenére, hogy az Egyesült Királyságban a közkiadások negyedét a helyi önkormányzatok költik el, az összes kormányzati bevételből kevesebb mint 10\%-ban részesednek (8. táblázat). A helyi bevételek összetételét tekintve pedig az adóbevételek jóval alacsonyabb részt képviselnek, mint a másik három ország esetén. A legtöbb adóbevételt a svéd önkormányzatok realizálják, hiszen a helyi bevételi források több mint 60\%-a adóból származik.

8. táblázat

Az önkormányzati bevételi szerkezet összehasonlító adatai, 2014

Comparative data of local government revenue structure, 2014

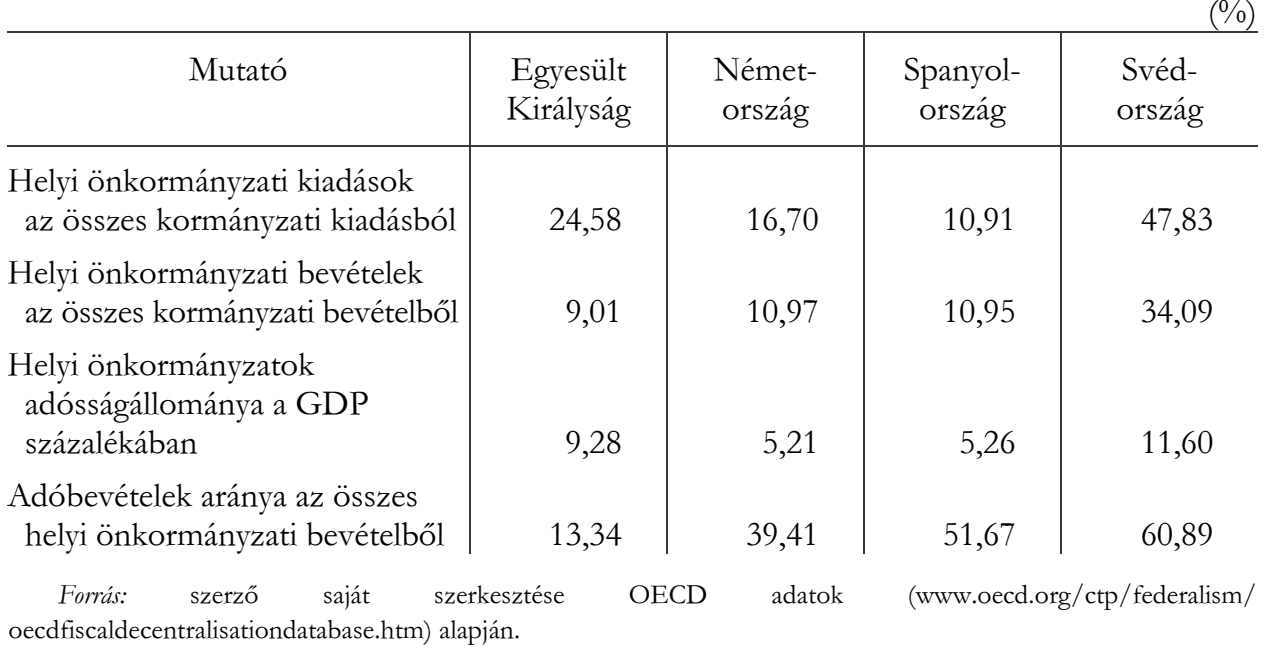

A kormányzati bevételekből való magas részesedés mellett ugyanakkor a svéd közkiadások közel fele a helyi szervekre jut. Ahogyan azt már a svéd helyi adórendszerben felmerülő problémáknál is említettük, a számottevő ellátandó közfeladat következtében az önkormányzatok adósságállománya európai

Területi Statisztika, 2016, 56(3): 320-345; DOI: 10.15196/TS560304 
összehasonlításban magasnak számít (közel 12\%). A vizsgált országok közül még az Egyesült Királyságban viszonylag magas (9\%-ot meghaladó) a helyi önkormányzatok eladósodottsága. (Összehasonlításképpen a magyar önkormányzatok GDP-hez viszonyított adósságállománya az adósságkonszolidáció előtt, 2010-ben és 2011-ben is jóval $6 \%$ alatt volt.)

A helyi bevételeken belül az adókból származó források Németországban és Spanyolországban is meghatározó szerepet kaptak. A német önkormányzatoknál a bevételek 40\%-a, míg a spanyoloknál több mint a fele adókból származott. A két országban a kormányzati bevételekből való helyi részesedés aránya szinte azonos.

A bevételek nagyságrendjének bemutatásához kiszámítottuk a 2013. adóévben befolyt helyi adóbevételek euróban kifejezett értékét (9. táblázat). Így az egy főre jutó helyi adóbevételek alapján összevetettük a négy ország önkormányzati adóbevételeit.

\section{Egy före jutó helyi adóbevétel országonként, 2013}

9. táblázat

Local tax revenue per capita by countries, 2013

\begin{tabular}{|c|c|c|c|c|}
\hline Mutató & $\begin{array}{l}\text { Egyesült } \\
\text { Királyság }\end{array}$ & $\begin{array}{l}\text { Német- } \\
\text { Ország }\end{array}$ & $\begin{array}{l}\text { Spanyol- } \\
\text { ország }\end{array}$ & $\begin{array}{l}\text { Svéd- } \\
\text { ország }\end{array}$ \\
\hline $\begin{array}{l}\text { Helyi adóbevétel, millió nemzeti } \\
\text { valuta }\end{array}$ & 27432 & 84963 & 34533 & 599307 \\
\hline Helyi adóbevétel, millió euró & 32303 & 84963 & 34533 & 69332 \\
\hline Lakosság, millió fő & 62,57 & 80,65 & 46,59 & 9,61 \\
\hline $\begin{array}{l}\text { Egy főre jutó helyi adóbevétel, } \\
\text { euró }\end{array}$ & 516,26 & 1053,53 & 741,16 & 7215,37 \\
\hline
\end{tabular}
alapján.

A vizsgált országok közül 2013-ban Svédország önkormányzatai realizálták egy főre vetítve a legtöbb adóbevételt, ami nem meglepő, ugyanis a svéd önkormányzatok esetén kiugróan magas az adóbevételek aránya a helyi források között, ráadásul a lakosságszám az ország területének nagyságához képest alacsony (a népsűrűség mindössze 22 fö $/ \mathrm{km}^{2}$ volt 2014-ben). ${ }^{12}$ Ezzel ellentétben az egyesült királyságbeli önkormányzatok részesedtek a legalacsonyabb arányban az adóbevételekből, amit az egy főre jutó mindössze 516 eurós helyi adóbevétel is tükröz. A spanyol önkormányzatok esetén 741, míg a német helyi szervek esetén 1053 euró adóbevétel jutott egy lakosra.

12 http://www.ksh.hu/docs/hun/xstadat/xstadat_eves/i_int001.html (letöltés ideje: 2016. február 17.). 


\section{Alkalmazott helyi adónemek}

Az önkormányzatok által bevezetett és bevezethető helyi adónemek változatos képet mutatnak Európában. A négy önkormányzati modellel azonban jól jellemezhető a helyi adórendszerek múködése és jellegzetessége. Angliában csak ingatlanadót vetnek ki a helyi szervek, ráadásul csak a magánszektorra vonatkozóan, míg Svédországban csak a személyi jövedelemadóból származik az önkormányzatok helyi adóbevétele. Ezzel szemben a német és a spanyol önkormányzatok többféle helyi adónemet is alkalmazhatnak, mobil és immobil adóalapra vonatkozóan egyaránt, ami sokszínúbbé teszi a helyi adórendszerüket, hiszen az adóbevételek így nem csupán egyetlen forrásból és nem csupán a magánszektorból származnak.

A vagyoni típusú adók, azon belül az ingatlanadó használatának számos előnyét élvezheti egy önkormányzat, hiszen az immobil adóalap stabil forrást biztosít, kiküszöböli az ingatlanértékek ingadozásából származó kockázatokat, független a gazdasági ingadozásoktól, így kiszámíthatóvá teszi az adóbevételeket, könnyen adminisztrálható, ráadásul a helyi viszonyoknak megfelelóen alakítható ki az adópolitika.

Az iparúzési adót több országban is alkalmazzák a közigazgatás helyi szintjén, annak ellenére, hogy számos kritika érte, elsősorban a társasági adóval való tulajdonképpeni összeférhetetlensége miatt. Vitathatatlan előnye, hogy a vállalkozási szektorra lehet hárítani az adófizetés domináns hányadát, és a gazdasági aktivitásukkal, valamint ezzel az adónemmel a szervezetük nagyságával arányosan adóztathatók az adóalanyok.

A vizsgált országok megoszlanak annak tükrében, hogy hány helyi adónem alkalmazását biztosítja a törvényhozás a helyi önkormányzatoknak. Az országok egy részében csupán egyetlen helyi adónem létezik, ezzel ellentétben van olyan ország is, ahol számos helyi adónem közül választhatnak a települések. A választási lehetőségek révén a helyi adópolitika a települési viszonyoknak megfelelően alakítható.

\section{A helyi adórendszerekben felmerülő problémák}

Az angol és a svéd helyi adóztatás tekintetében problémát jelent, hogy csupán egyetlen helyi adónemet vezethetnek be az önkormányzatok, ráadásul zárt listás módszert alkalmazva múködik az adónem (Kecső 2013), melynek következtében csak arra van hatáskörük, hogy a D-sáv adótételét, valamint a személyi jövedelemadó helyi kulcsát meghatározzák és az adókedvezményekről, valamint a mentességekről döntsenek, tehát adóbevételeik növelése csak az adómérték emelésével érhetô el.

A svéd önkormányzati rendszerben alkalmazott jövedelemkiegyenlítés révén megvalósul, hogy az ország egyik szegmense sincs „megfosztva” a nemzeti jóléttől a költségvetési különbségek kiegyenlítése által. A rendszer előnye az adófizetők szempontjából, hogy kiküszöböli az önkormányzatok túlzott adómérték-növelésének veszélyét. Ugyanis az önkormányzatok nem érdekeltek a minél magasabb bevételek

Területi Statisztika, 2016, 56(3): 320-345; DOI: 10.15196/TS560304 
realizálásában, hiszen a többletet úgyis átcsoportosítják a hátrányosabb helyzetú önkormányzatokhoz. Emellett az adófizetők szemszögéből megemlítendő, hogy nem szívesen finanszírozzák adójukból a többi önkormányzat kiadásait.

Problémát jelent emellett ugyancsak az angol és a svéd rendszerben, hogy a tanácsi adó és a helyi jövedelemadó hatálya csak a természetes személyekre terjed ki, a vállalkozási szektorra nem. Ebből kifolyólag a helyi önkormányzatok adópolitikájukkal nem tudják befolyásolni a helyi gazdaságot, nincs eszközük arra, hogy ösztönözzék a helyi gazdaság teljesítményét vagy hatást gyakoroljanak a vállalkozások telephely-választási döntéseire.

Az ingatlanadózás tekintetében jelentős problémát okoz az ingatlanok értékelési módszere, hiszen Angliában és Németországban is rendkívül elavult adatokra épülve történik az értékelés. Angliában a jegyzék a elkészítésétől fogva nem lett frissítve, így a benne szereplő értékek nem alkalmazkodnak a jelenlegi lakáspiaci helyzethez, ami korántsem segíti eló a vagyoni helyzetnek és a teherbíró képességnek megfelelő adóztatást. Az 1991. április 1-je után épült lakások felértékelésekor azt veszik figyelembe, hogy mekkora lehetett volna a lakás ingatlanpiaci ára 1991-ben. $\mathrm{Az}$ ingatlanok újraértékelésére csak kivételes esetekben kerül sor ${ }^{13}$. A német ingatlanok értékelési módszerének vonatkozásában sem lehet figyelmen kívül hagyni, hogy az 1964-es ingatlanpiaci árakhoz mérten veszik nyilvántartásba az ingatlanokat. Az elavult értékelési rendszer felváltásán már évek óta munkálkodnak, a 2007. január 1-jei ingatlanpiaci értékeket akarták viszonyítási alapnak (Deutscher Bundestag 2014), ám a megoldás még várat magára. Ezekhez hasonlóan a spanyol helyi adórendszerben múködtetett ingatlanértékelésnél is felmerül az a probléma, hogy az értékelést központilag végzik, holott a központi szerveknek nem áll olyan szinten az érdekükben a pontos értékelés, mint a települési szerveknek, hiszen a bevételből csak a települések részesednek. Annak ellenére, hogy a helyi szintû értékelés többletfeladatot eredményezne a helyi hatóságoknál, célszerû lenne a településekre bízni, mivel helyismeretükkel pontosabban megállapíthatnák a piaci értékeket. Az ingatlanadózás vonatkozásában összességében megállapíthatjuk, hogy szükség van az értékelési módszerek frissítésére vagy megváltoztatására, hiszen a több évtizeddel korábbi piaci értékekhez viszonyításnál a magyar helyi adóztatásban is alkalmazott, hasznos alapterület alapján történő adóztatás is hủebben tükrözné a valós állapotokat.

A német és a spanyol helyi adórendszer több helyi adónemet is múködtet, így sokszínúbb helyi adóalapot biztosít az önkormányzatoknak. Ennek ellenére ezek a helyi adórendszerek sem problémamentesek. Az iparúzési adó a vagyoni típusú adókkal ellentétben nem konjunktúrasemleges, a bevételek ugyanis nem függetlenek a gazdasági ingadozásoktól. Az egy főre jutó iparűzésiadó-bevétel már nagyobb

${ }^{13}$ A lakás átértékelésére kerül sor például, ha részben vagy egészben megsemmisül, egybenyitják egy másikkal vagy leválasztják, vagy ha értékesítésre kerül, akkor az értéknövelő beruházások végett szükséges az új érték meghatározása, továbbá ha jelentős változások történnek az ingatlan térségében. (Forrás: www.gov.uk/council-tax letöltés ideje: 2016. február 15.)

Területi Statisztika, 2016, 56(3): 320-345; DOI: 10.15196/TS560304 
eltéréseket mutathat az egyes települések között, hiszen nem ritkán előfordul, hogy egy-egy önkormányzat adóbevételének nagy része csupán egy vagy két domináns vállalattól származik. A német helyi és fényűzési adók ugyan még nagyobb döntési szabadságot biztosítanak a helyi költségvetések kialakításában, de a belőlük származó bevételek - elenyésző összegük miatt - csak bonyolítják a helyi adórendszert, ráadásul magas adminisztrációs költségvonzatuk is lehet.

\section{Következtetések}

Az országok helyi önkormányzati rendszereinek sokszínúsége, a felépítésük és a múködésük változatossága összefügg a történelmi, a kulturális, a politikai fejlődéssel és a hagyományokkal. Európában a rendszerek különbözőségéből fakadóan végső soron nem lehet sem az önkormányzati hatásköröket, sem a döntési kompetenciákat és jogköröket, sem pedig a gazdálkodási feltételeket uniformizálni, hiszen az egységesítéshez nem csupán az önkormányzatok múködésének szabályozását, hanem az országok egész államháztartási berendezkedését és múködési mechanizmusait újra kellene formálni. Az adórendszerek egységesítését a különbözőségek és a hagyományok mellett elsősorban az országok szuverenitása gátolja.

A tanulmányban szereplő helyiadórendszer-típusok jellegzetességeit a vizsgált országok helyi adórendszerének sajátosságai húen bemutatják. Az angolszász önkormányzati modellre a helyi igazgatás megosztottsága jellemző, melyet a leginkább Anglia közigazgatási rendszere tükröz, ahol a helyi közfeladatok köre szúkebb, az önkormányzati jog- és hatáskörök nagyobb mértékben behatároltak, mint a kontinentális modellben. Ezt támasztja alá az is, hogy egyetlen helyi adónem létezik az angol önkormányzatoknál, melyre nincs is a helyi szerveknek számottevő befolyása. A skandináv típusú önkormányzati modellben a közfeladatok széles köre a magas lakosságszámú helyi önkormányzatok hatáskörébe tartozik, melynek pénzügyi forrását Svédországban a jövedelemadóra kivetett helyi pótadó biztosítja. A francia modell kisközséges (helyi és regionális) közigazgatási szerveződésének bemutatására Spanyolország önkormányzati rendszere kiválóan alkalmas, ahol az önkormányzatok, hasonlóan a germán típusú önkormányzati modellt képviselő Németországhoz, a kötelezően alkalmazandó helyi adók mellett többféle adónem bevezetéséről dönthetnek. Hazánk a vegyes önkormányzati modellhez tartozik. A magyar helyi adórendszerről megállapítható, hogy európai összehasonlításban is széles mozgásteret biztosít a helyi önkormányzatok adóztatási tevékenységében, hiszen nemcsak az adómértékekról, hanem az adónemek, többek között a magas bevételt biztosító iparűzési adó és ingatlanadók bevezetésérôl is dönthetnek a helyi önkormányzatok, nem megfeledkezve arról sem, hogy a települési adó esetében rendkívül széles az adótárgyra vonatkozó választási lehetőségek köre.

A négy elemzett önkormányzati modell vizsgálatából megállapítható, hogy a helyi adóztatás csupán egyik eszköze a vertikális közpénzügyi egyensúly kialakitásának és

Területi Statisztika, 2016, 56(3): 320-345; DOI: 10.15196/TS560304 
fenntartásának. Az európai helyi önkormányzatok magas támogatásfüggősége következtében a közigazgatásban az állami transzferek, támogatások rendszerének megfelelő kialakítása épp olyan fontos, mint a helyi adórendszerek múködtetése. Megállapítható továbbá, hogy a regionális (megyei) közigazgatási szektor önkormányzatai a helyi önkormányzati szintnél az esetek túlnyomó többségében korlátozottabban jogosultak az adóztatásra.

Az alkalmazott helyi adónemek típusait tekintve kijelenthető, hogy az ingatlanadóból származó bevételek stabil forrást jelentenek az önkormányzatoknak, az immobil adóalapoknak köszönhetően. Ugyanakkor a vagyoni típusú adók nem követik a jövedelmek és az infláció növekedését, a vagyontárgyak naprakész értékelése viszont költséges feladat lenne. Számottevő bevételre akkor lehet számítani ezekből az adókból, ha azok mind a lakosságot, mind a vállalkozási szférát terhelik. A vagyoni típusú adóztatás helyett vagy mellett számos európai ország alkalmaz mobil adóalapú helyi adónemeket. A jövedelem- és a nyereségadókat az önkormányzatok általában pótadó formájában vetik ki. A skandináv modell elemzésének eredményeiből megállapítható, hogy a helyi jövedelemadó alkalmazása hatékony helyi adóztatási módszer.

Összegzésként megállapítható, hogy az „ideális” helyi adórendszerben szükség van egy olyan domináns adónemre, amely az adófizetők széles körére kiterjed, annak érdekében, hogy az általánosság és az egyenlőség alapelve ne sérüljön. Emellett több helyi adó alkalmazása célszerű, hiszen amennyiben az önkormányzatoknak lehetősége van az adóbevételek nagyságrendjén, vagyis az adómértékeken kívül az adóbevételek összetételét is meghatározni, azaz kiválasztani, milyen típusú helyi adónemeket akarnak kivetni, úgy megvalósulhat a rugalmas helyi adórendszer, az önkormányzati költségvetések kialakítása szabadabbá válhat és a bevételek jobban tervezhetők.

\section{IRODALOM}

Bundesministerium der Finanzen (2013): Steuern von A bis Z, pp. 28-29.

Department for Communities and Local Government (2015): Local Government Financial Statistics England, No. 25 2015, London.

Deutscher Bundestag (2014): Grundstener(-reform). Nr. 14/14 (16. Mai 2014).

Ekonomistyrningsverket (2015): Prognos Statens budget och de offentliga finanserna, Juni.

ERDŐs, É. (2008): Az adójogi harmonizáció problémái a helyi adózásban. Sectio Juridica et Politica, 2008/1, pp. 305-324.

Esping-Andersen, G. (1990): The Three Worlds of Welfare Capitalism. Princeton UniversityPress, Princeton, New Jersey, pp. 26-32.

KARA, P. - KÖKÉNYESI, J. (2007): Önkormányzati közigazgatás. Közigazgatási Szakvizsga Jegyzet, Kormányzati Személyügyi Szolgáltató és Képzési Központ, Budapest, pp. 13-14.

KECSŐ G. (2013): A belyi önkormányzatok gazdálkodásának egyes kérdései nemzetteözi kitekintésben. Új Magyar Közigazgatás, 6. évf. 2013/1, pp. 11-12.

Ministerio De Hacienda Y Administraciones Públicas (2009-2013): Haciendas Locales en Cifras.

Területi Statisztika, 2016, 56(3): 320-345; DOI: 10.15196/TS560304 
OECD (2015): Subnational Governments in OECD Countries: Key Data, 2015 edition.

Statistisches Bundesamt (2015): Finanzen und Steuern 2014, Realsteuervergleich, Wiesbaden, Fachserie 14 Reihe 10.1.

Swedish Association of Local Authorities and Regions (2011): The Creditworthiness of Swedish Local Governments, Stockholm and Örebro, December.

VIgVÁRI, A. (2011): Önkormányzati pénzügyek - Hazai kibivások és nemzetközi példák. Állami Számvevőszék Kutató Intézete, Budapest.

\section{HIVATKOZOTT JOGSZABÁLYOK}

Constitución Española, 1978. (utoljára módosítva: 2011. szeptember 27-én)

Grundgesetz für die Bundesrepublik Deutschland, 1949. (utoljára módosítva: 2014. december 23-án)

Grundlagarna, (négy alappillére: Kormányzati Okirat 1974, Törvény a Sikerességről 1810, Törvény a Sajtószabadságról 1949 és Törvény a Szólás Szabadságról 1991)

Helyi Önkormányzatok Európai Chartája, Strasbourg, 1985. október 15.

Inkomstskattelagen (1999:1229) (utoljára módosítva: 2016. április 1-jén)

Lag (2004:773) om kommunalekonomisk utjämning (utoljára módosítva: 2015. október 10-én)

Local Government Finance Act (1992) (utoljára módosítva: 2016. január 28-án)

Localism Act (2011) (utoljára módosítva: 2016. január 28-án)

Texto Refundido de la Ley Reguladora de las Haciendas Locales, Real Decreto Legislativo (2004), rövidítve RDLeg. 2/2004

\section{INTERNETES HIVATKOZÁSOK}

https://dits.deloitte.com/\#TaxGuides (letöltés ideje: 2016. február 10.)

http://stats.oecd.org/ (letöltés ideje: 2016. február 10.)

http:/ / taxsummaries.pwc.com/uk/taxsummaries/wwts.nsf/ID/tax-summaries-home (letöltés ideje: 2016. február 10.)

http://www.gov.uk/council-tax (letöltés ideje: 2016. február 15.)

http://www.ec.europa.eu/eurostat/ (letöltés ideje: 2016. február.12.)

http://www.oecd.org/ctp/federalism/table16_tax_revenue_na-log_rev_internal.xls (letöltés ideje: 2016. február 10.)

http://www.oecd.org/ctp/federalism/oecdfiscaldecentralisationdatabase.htm\#A_1 (letöltés ideje: 2016. február 15.)

http://www.skatteverket.se/ (letöltés ideje: 2016. február 15.)

http://www.scb.se/ (letöltés ideje: 2016. február 15.)

Területi Statisztika, 2016, 56(3): 320-345; DOI: 10.15196/TS560304 